Research Article

\title{
Evaluation of analgesic self-medication pattern among under-graduate medical students of Adichunchanagiri Institute of Medical Sciences, BG Nagar, Karnataka: a cross-sectional questionnaire-based study
}

\author{
Shwetha Shivamurthy, Ravishankar Manchukonda*, Deepika Gurappanavar
}

\begin{abstract}
Department of Pharmacology, Adichunchanagiri Institute of Medical Sciences, Mandya, Karnataka, India
\end{abstract}

Received: 06 March 2015 Accepted: 24 April 2015

\author{
*Correspondence to: \\ Dr. Ravishankar \\ Manchukonda, \\ Email: ravipharmac@yahoo. \\ com
}

Copyright: (C) the author(s), publisher and licensee Medip Academy. This is an openaccess article distributed under the terms of the Creative Commons Attribution NonCommercial License, which permits unrestricted noncommercial use, distribution, and reproduction in any medium, provided the original work is properly cited.

\begin{abstract}
Background: Self-medication with analgesics is widely practiced among medical students. Self-medication is defined as "the selection and use of medicines by individuals to treat self-recognized illnesses or symptoms." It assumes a special significance among the undergraduate medical students as they are aware of the available analgesic medications. Our study would evaluate the pattern of analgesic self-medication among undergraduate medical students of Adichunchanagiri Institute of Medical Sciences (AIMS), BG Nagar.

Methods: A cross-sectional questionnaire-based study was done from January to March 2014 among undergraduate medical students, AIMS, BG Nagar. 218 students consented for the study out of 250 students and filled in the questionnaire. 20 incomplete questionnaires were excluded and the remaining 198 were analyzed. Results: Our study showed that $63.6 \%$ of the students practiced analgesic selfmedication. $68.2 \%$ sought self-medication for headache followed by body pain (9.7\%), low backache (5.1\%), fever $(4.5 \%)$ and joint pain $(3.8 \%)$. Paracetamol was used by $47.2 \%$, diclofenac by $20.5 \%$, ibuprofen by $7.5 \%$, aspirin by $6.8 \%$, and aceclofenac by $4.1 \%$. Self-medication was based on the use of previous prescriptions in $42.1 \%$ of the students and textbook knowledge in $39.1 \%$ of the students. $26.4 \%$ students complained that pain reduced concentration in studies. $61.6 \%$ students stated the mild nature of illness as the reason for self-medication. $91.9 \%$ of the students felt that self-medication is a part of self-care. $61.2 \%$ of the students were aware of the side-effects of the analgesic medications.

Conclusion: Our study shows that self-medication with analgesics is high among the undergraduate medical students of this institute. Although it is an easy way to treat mild to moderate pain, it may be accompanied with side effects, drug interactions, and toxicities. Hence, we conclude that there is a need to create awareness, and educate the students regarding the possible harmful effects of self-medication with analgesics.
\end{abstract}

Keywords: Self-medication, Analgesics, Undergraduate medical students, Side effects, Drug interactions, Toxicities

\section{INTRODUCTION}

In the developing countries, $60-80 \%$ of health problems are due to self-medication ${ }^{1}$ and the drugs are dispensed over the counter without medical supervision. ${ }^{2}$ There is an increase in the trend for self-care which resulted in self-medication with powerful drugs including drug combinations. $^{3}$ People resort to self-medication since it's a lower cost alternative for people who cannot afford the cost of clinical service. Studies have revealed that the increase in self-medication was due to a number of factors. These included socioeconomic factors, lifestyle, ready access to drugs, the increased potential to manage certain illnesses through self-care, and greater availability of medicinal products. ${ }^{2}$

Analgesic self-medication is widely prevalent among undergraduate medical students. A study conducted at the All India Institute of Medical Sciences, New Delhi observed that self-medication was considerably high among undergraduate medical and paramedical students in India and it increased with medical knowledge. ${ }^{4}$

Pain problems are important reasons for self-medication of analgesics. One of the most common complaints for the use of analgesic self-medication is headache. Around $25 \%$ 
patients are not happy with the physician's treatment for headache and $45 \%$ migraine patients do not take advice of physician for headache and take self-medications for relief of headache. ${ }^{5}$

In India, there is a paucity of literature on the prevalence of analgesic self-medication especially among the young population who are highly influenced by media advertisements and internet which promote self-medication. This raises concerns of incorrect self-diagnosis, drug interactions, and use of drugs other than for the original indication. ${ }^{6}$ The present study was hence conducted to evaluate the prevalence of analgesic self-medication among the under-graduate students of Adichunchanagiri Institute of Medical Sciences (AIMS), BG Nagar with the following aims and objectives:

1. To find out the common health-related problems leading to self-medication with analgesics

2. To find out the commonly used analgesics

3. To find out the students' attitude on self-medication and impact of pain on their quality of life.

\section{METHODS}

A cross-sectional observational study was carried out among the under-graduate students of AIMS during January-March 2014. A pre-designed semi-structured questionnaire was used to collect the relevant information pertaining to the study variables. The questionnaires were distributed to the medical under-graduates from the $1^{\text {st }}, 2^{\text {nd }}, 3^{\text {rd }}$, and $4^{\text {th }}$ year of MBBS after obtaining ethical clearance from the Institutional Ethics Committee, AIMS, BG Nagar. The students were briefed on the aims and objectives of the study. The study subjects were informed that the information collected would be kept anonymous and participation would be totally voluntary.

The age, sex, and year of study of the students were noted. The information regarding: (1) type of medication, (2) type of illness for which the medication was used, (3) reason for not consulting a doctor, (4) their attitude toward selfmedication, (5) source of information, (6) effect of pain on quality of life for those who practiced self-medication was recorded.

Totally, 218 students consented for the study out of 250 students and filled in the questionnaire. 20 incomplete questionnaires were excluded and the remaining 198 were analyzed. The questionnaires were assessed for their completeness and only the completed questionnaires were considered for the final analysis.

Ethical clearance was obtained from the Institutional Ethics Committee of AIMS, BG Nagar, Mandya district, Karnataka, India prior to the commencement of the study.

The results were expressed in numbers and percentage.

\section{RESULTS}

Our study showed $63.6 \%$ students of AIMS practiced selfmedication. Female students $(59.5 \%)$ outnumbered males $(40.4 \%)$

\section{DISCUSSION}

As per the World Health Organization, "self-medication is the selection and use of medicines by individuals to treat self-recognized illnesses or symptoms." Self-medication is considered an element of self-care. ${ }^{7}$ In studies conducted within India, the prevalence of self-medication among the undergraduate medical students was shown to be ranging between $57.1 \%$ and $92 \% .^{8-10}$

Analgesics have been the most commonly used selfmedication as seen in previous studies. ${ }^{11-15}$ Self-medication by itself has both pros and cons that depend on who and what one chooses to self-medicate. ${ }^{16}$ The present study was conducted to evaluate the practices, attitude and perception of analgesic self-medication among undergraduate medical students.

The prevalence of analgesic self-medication in our study was found to be $63.6 \%$. In our study, headache was the most common reason for practicing self-medication (Table 2). Paracetamol is the most common drug being used as an analgesic (Table 1). Repeated consumption of paracetamol can cause adverse drug reactions like liver damage and drugs interactions like paracetamol toxicity if taken with alcohol/ other enzyme inducers due enzyme induction. Repeated use of other analgesics is associated with adverse renal effects and gastric ulceration or bleeding. ${ }^{17}$

The most common reason for analgesic self-medication reported by students was the illness being too trivial (Table 4). Similar observations were reported in a few studies from India. ${ }^{8,10}$ However, in a study from Tamil $\mathrm{Nadu}^{18}$ most students practiced self-medication as it was time-saving, whereas in Punjab ${ }^{19}$ the most common reason for self-medication was for quick relief. Students are prone to make unsupervised health-related decisions especially the students of health sciences who feel confident of their knowledge about the drugs. In the present study, 39.1\% of the participants indulged in self-medication owing to their sufficient pharmacological knowledge (Table 3). In studies from Ethiopia, ${ }^{20,21}$ Karachi, ${ }^{22}$ and Malaysia, ${ }^{23}$ prior experience with the illness was observed to be the most common reason for self-medication. Previous prescription for the same illness was reported as the most common source of information about the drugs used for self-medication in the present study, which was similar to the observation made in Tamil Nadu ${ }^{18}$ and Uttar Pradesh. ${ }^{24}$ However, in another study from India, ${ }^{10}$ and Ethiopia ${ }^{20}$ textbooks were reported as the most common source of information analgesics are associated with adverse renal effects. 
Table 1: Drugs used by the students for self-medication.

\begin{tabular}{|lc|}
\hline Drugs & $\%$ \\
\hline Paracetamol & 47 \\
\hline Diclofenac & 20.5 \\
\hline Ibuprofen & 7.5 \\
\hline Aspirin & 6.8 \\
\hline Nimesulide & 6.8 \\
\hline Aceclofenac & 4.1 \\
\hline $\begin{array}{l}\text { Spasmoproxyvon (dicyclomine+paracetamol+ } \\
\text { propoxyphene napsylate) }\end{array}$ & 2 \\
\hline Combiflam (ibuprofen+paracetamol) & 1.3 \\
\hline Cyclopam (dicyclomine) & 1.3 \\
\hline Diclogel (diclofenac gel) & 1.3 \\
\hline Tramadol & 0.6 \\
\hline
\end{tabular}

Table 2: Most common site of pain.

\begin{tabular}{|lc|}
\hline Site & $\%$ \\
\hline Headache & 68.2 \\
\hline Body pain & 9.7 \\
\hline Low backache & 5.1 \\
\hline Fever & 4.5 \\
\hline Joint pain & 3.8 \\
\hline Abdominal pain & 3.8 \\
\hline Neck pain & 1.9 \\
\hline Migraine & 1.2 \\
\hline Tooth-ache & 0.6 \\
\hline Ear-ache & 0.6 \\
\hline
\end{tabular}

Table 3: Awareness of medicine.

\begin{tabular}{|lc|}
\hline Source of awareness & $\%$ \\
\hline Previous doctor prescription & 42.1 \\
\hline Textbooks & 39.1 \\
\hline Advertisements & 11.4 \\
\hline Others & 7.2 \\
\hline
\end{tabular}

Table 4: Reason for self-medication.

\begin{tabular}{|lc|}
\hline Reason for self-medication & $\%$ \\
\hline Mild nature of the illness & 61.6 \\
\hline Easy and effective & 16.1 \\
\hline Self confidence & 14.9 \\
\hline Saves time and money & 7.1 \\
\hline
\end{tabular}

In the present study, $91.97 \%$ of the participants felt that selfmedication was part of self-care (Table 6), which was higher to that reported in studies from Ethiopia ${ }^{21}$ and Karachi. ${ }^{22}$ Participants wished to continue with self-medication/start self-medication. They were even ready to advice selfmedication to their friends.
Table 5: Effect of pain on quality of life.

\begin{tabular}{|lc|}
\hline Effect of pain on quality of life & $\mathbf{\%}$ \\
\hline Trouble in concentration & 26.4 \\
\hline Unable to sleep & 18.8 \\
\hline Reduced energy level & 16.9 \\
\hline Missed class & 15 \\
\hline Reduced overall enjoyment & 13.2 \\
\hline Depression & 9.4 \\
\hline
\end{tabular}

Table 6: Attitude toward self-medication.

\begin{tabular}{|lc|}
\hline Attitude & $\%$ \\
\hline Part of self-care & 91.97 \\
\hline Continue with the self-medication & 3.2 \\
\hline Advise self-medication to friends & 4.8 \\
\hline
\end{tabular}

The irrational use of drugs is a cause of public and professional concern. Self-medication as part of selfcare can be justified only when there is a judicial use of medicines. There is always a risk of using expired drugs, sharing them with friends or taking medicine that have been originally prescribed for some other problem. Irrational use of drugs may result in accidental drug poisoning. Other problems related to self-medication are wastage of resources and serious health hazards such as drug dependence, adverse reactions, and prolonged suffering. ${ }^{25}$

\section{CONCLUSION}

About $63.6 \%$ students of AIMS were practicing analgesic self-medication with paracetamol, diclofenac, aspirin etc., with mild nature of the illness being the most common cause. Although self-medication is an easy way to treat mild to moderate pain, it may be accompanied with side effects, drug interactions, and toxicities. Hence, we conclude that there is a need to create awareness and educate the undergraduate medical students regarding the possible harmful effects of self-medication with analgesics.

\section{ACKNOWLEDGMENTS}

We are thankful to the department of anatomy for enabling us to collect the data required during their dissection hours. We also thank the students of all the years for having voluntarily and enthusiastically participating in the questionnaire-based study.

Funding: A.I.M.S, BG Nagar

Conflict of Interest: None declared

Ethical approval: The study was approved by the Institutional Ethics Committee 


\section{REFERENCES}

1. Awad AI, Eltayeb IB. Self-medication practices with antibiotics and antimalarials among Sudanese undergraduate university students. Ann Pharmacother. 2007;41(7):1249-55.

2. Brudon-Jakobowicz P. World Drug Situation. Geneva: WHO; 1988.

3. Blenkinsopp A, Bradley C. Patients, society, and the increase in self-medication. BMJ. 1996;312(7031):629-32.

4. Self-medication popular among medical students: AIIMS study. Available at: http://www.livemint.com/ Politics/XcN44QD5g8aW4dwltcUdtI/Selfmedicationpopular-among-medical-students-AIIMS-study.html. Accessed 06 Mar 2015.

5. Robinson RG. Pain relief for headaches. Is self-medication a problem? Can Fam Physician. 1993;39:867-8, 871.

6. Burak LJ, Damico A. College students' use of widely advertised medications. JAm Coll Health. 2000;49(3):118-21.

7. The Role of the Pharmacist in Self-Care and Self-Medication. Available at: http://www.apps.who.int/medicinedocs/pdf/ whozip32e/whozip32e.pdf. Accessed 06 Mar 2015.

8. Banerjee I, Bhadury T. Self-medication practice among undergraduate medical students in a tertiary care medical college, West Bengal. J Postgrad Med. 2012;58(2):127-31.

9. Sontakke SD, Bajait CS, Pimpalkhute SA, Jaiswal KM, Jaiswal SR. Comparative study of evaluation of selfmedication practices in first and third year medical students. Int J Biol Med Res. 2011;2(2):561-64.

10. Badiger S, Kundapur R, Jain A, Kumar A, Pattanshetty S, Thakolkaran N, et al. Self-medication patterns among medical students in South India. Australas Med J. 2012;5(4):217-20.

11. Keche Y, Yegnanarayan R, Bhoyar S, Agrawal R, Chavan R, Mahendrakar P. Self-medication patterns in rural areas in Pune, India. Int J Med Public Health. 2012;2(4):7-11.

12. Loharkar N, KecheY, Yegnanarayan R, Dharma M, BhosaleA, Makan A. Self-medication use in Urban population of Pune, Maharashtra, India. Sch J Appl Med Sci. 2013;1(6):732-8.

13. Shankar PR, Partha P, Shenoy N. Self-medication and nondoctor prescription practices in Pokhara valley, Western Nepal: a questionnaire-based study. BMC Fam Pract. 2002;3:17.

14. Keche Y, Patil D. Self-medication use in Nagpur City, Central India. Invent Impact Pharm Pract. 2010;1(1):22-4.

15. Sharma R, Verma U, Sharma CL, Kapoor B. Self-medication among Urban population of Jammu City. Indian J Pharmacol. 2005;37(1):37-45.
16. Dangers of Self Medication. Available at: http://www. healthguidance.org/entry/15933/1/Dangers-of-SelfMedication.html. Accessed 06 Mar 2015.

17. Tripathi KD. Essentials of Medical Pharmacology. 7th Edition. New Delhi: Jaypee Brothers Medical Publishers (P) Ltd.; 2013.

18. Kayalvizhi S, Senapathi R. Evaluation of the perception, attitude and practice of self-medication among business students in 3 select cities, South India. Int J Enterp Innov Manag Stud. 2010;1(3):40-4.

19. Gupta V, Bansal P, Manhas R, Singh Z, Ghaiye P. Preferred system of medicine and reasons of self-medication among college students in Malwa region of Punjab. J Drug Deliv Ther. 2011;1(2):27-9.

20. Abay SM, Amelo W. Assessment of self-medication practices among medical, pharmacy, and health science students in Gondar University, Ethiopia. J Young Pharm. 2010;2(3):306-10.

21. Gutema GB, Gadisa DA, Kidanemariam ZA, Berhe DF, Berhe AH, Hadera MG, et al. Self-medication practices among health sciences students: the case of Mekelle University. J Appl Pharm Sci. 2011;01(10):183-9.

22. Zafar SN, Syed R, Waqar S, Irani FA, Saleem S. Prescription of medicines by medical students of Karachi, Pakistan: a cross-sectional study. BMC Public Health. 2008;8:162.

23. Ali SE, Ibrahim MI, Palaian S. Medication storage and selfmedication behaviour amongst female students in Malaysia. Pharm Pract (Granada). 2010;8(4):226-32.

24. Verma RK, Mohan L, Pandey M. Evaluation of self medication among professional students in North India: proper statutory drug control must be implemented. Asian J Pharm Clin Res. 2010;3(1):60-4.

25. Sarkar P, Gould IM. Antimicrobial agents are societal drugs: how should this influence prescribing? Drugs. 2006;66(7):893-901.

doi: $10.18203 / 2319-2003$. ijbcp20150010

Cite this article as: Shivamurthy S, Manchukonda R, Gurappanavar D. Evaluation of analgesic self-medication pattern among under-graduate medical students of Adichunchanagiri Institute of Medical Sciences, BG Nagar, Karnataka: a cross-sectional questionnaire-based study. Int J Basic Clin Pharmacol 2015;4:438-41. 